\title{
Money for Universities
}

\author{
by our Special Correspondent
}

\begin{abstract}
Should university finance be subject to inspection by the Comptroller and Auditor-General? The Committee of Public Accounts of the House of Commons has recently considered the question, and has recommended that inspection should begin in 1967-8. The minutes of evidence taken by the committee show that many people doubt the wisdom of this decision.
\end{abstract}

Sir JoHN WOLFENDEN, chairman of the University Grants Committee, told the committee how the U.( $x$.C. finances the universities. The five year block grant, he said, was seen as imposing on the universities a very serious respon. sibility. "A university knows for five years in advance, at any rate at the beginning of the quinquennium, what its income will be, and within that income it must stay." The academic in-fighting in the senate, Sir John said, means that if a university spends its money on one thing it cannot spend it on another; this is a built-in inducement to economy. By nature, he added, universities are bound to try to be economical, though he doubted if that was quite the same thing as knowing in detail how to. Asked if the U.G.C. consults the Department of Education and Science about the more expensive building projects, Sir John said that the criterion of cost was not discussed. The arrangement seems to be that the U.G.C. submits a list of building starts to the department, and if the total falls beneath the ceiling established for that year's building starts, the list is approved. Any building start of value more than $£ 30,000$, however, is examined individu. ally by the department. Being more specific about the procedure, Sir John described it in terms of a three phase process; first, the universities tell the U.G.C. what they want to do. Then the U.G.C. finds out from the D.E.S. how much money is going to be available, and knowing this, reconsiders the bids submitted by the universities and decides which are the best to back within the ceiling set. D.E.S. approval is then likely to be a formality.

\section{Cost Control}

Moving to cost control, Sir John said that his experience had convinced him that the universities would not object to an exercise in cost control; the difficulties that the U.G.C. had found in trying to work out the costs of an individual student had been caused by the crude and unsophisticated way that it had set about it. Sir John went on to add that there was a danger in this sort of accounting-_I would really rather earnestly plead that this is not simply an arithmetical matter . . . if examina. tion by the Comptroller and Auditor-General resulted simply in pressure for an arithmetical formula as the controlling thing, then I would be very sorry". Sir John also spoke of "centres of excellence", a phrase for which he expressed some distaste. The concept, however, he seems to accept, with the reservation that "it is not really an either/or situation, that you have got to have concentration and specialization, or you aro landed with a uniform sprcad which can only result in mediocrity. . . . $I$ think we have got to combine the best elements of both".

In its memorandum to the Public Accounts Committee, the Committec of Vice Chancellors and Principals expressed its fears about the involvement of the Comptroller and Auditor-General in university finance. The principle that the D.F.S. should not interfere with university freedom was not at issue, the memorandum says; this is agreed by everybody. What was at issue was whether the investigations by the Comptroller and Auditor-General would involve the D.E.S. in parliamentary controversy which would in turn force the department to take a much more detailed interest in university expenditure. The D.E.S. would no longer remain at one remove from the universities, with the U.G.C. acting as a buffer, and this would be damaging to the universities, whose efficiency is "a funetion of their academic freedom and initiative". This theme is the basis of the memorandum, and it was expanded when the committee gave evidence. Asked by the chairman of the Public Accounts Commit. tee, Mr. Boyd-Carpenter, whether the committee would find control by the U.G.C. more or less objectionable than control by the department, Sir Charles Wilson said that he thought it would be less objectionable, but that it would certainly be followed, in his opinion, by an increase of control by the department. He agreed that intervention by the U.G.C. in "housekeeping details" of university expenditure had increased in recent years, and suggested cautiously that this might have reduced academic freedom. The area of discretion left to the universities was, he thought, vital.

Asked to give a concrete example of the way in which he felt examination by the Comptroller and AuditorGeneral would be an intrusion into university freedom, Sir Charles quoted the example of his own university, the University of Glasgow. In the medical school, a change had been made in which the fourth year of the five or six year course had been turned into an integrated year, in which everybody was taught together. The cost of this experiment had turned out to be considerable. How could one say whether the experiment was good value for money? The Comptroller and Auditor-General, Sir Bruce Fraser, replying, said that if he were auditing the books and found an increase of this type, he would ask why. If he were told that the increase had come about as a deliberate decision of academic policy, that is all he would wish to know. "I would say no more about it. It would be ridiculous for me to try to substitute my judgment for the academic judgment of the people who know about it. This is not the way the Comptroller and Auditor-General ever, ever works." Sir Charles Wilson said that if his fears had been based on a misunderstanding of the memorandum prepared for the Public Accounts Commit. tee by the previous Comptroller and Auditor-General, he would bo glad to have misunderstood it. The original memorandum had, he thought, been more wide-ranging than Sir Bruco Fraser had suggested.

\section{Hospitals}

The discussion then turned to the hospitals, which are subject to the inspection of the Comptroller and Auditor-General. Sir Robert Aitken said that he thought that adverse consequences had followed from this inspoc- 
tion; the controls were closer, and the machine operated much more slowly. Sir Bruce Fraser, drawing on his previous experience as Permanent Secretary of the Ministry of Health, said that it was not the audit but the fact that the ministry had never provided enough money which had caused this situation.

Mr. Sheldon of the Public Accounts Committee suggested that it was unreasonable to object to an audit by the Comptroller if the universities were prepared to accept increasing control by the U.G.C. "It seems very much like the question of just accepting the devil one knows even if his horns are growing rapidly", he said. Sir Charles Wilson replied that U.G.C. control might be acceptable alone, but increased departmental control in addition would be too much. "It is to pile Pelion upon Ossa", he said.

The Association of University Teachers, which met the Committee of Public Accounts two days later, was treated far less tenderly, probably because it criticized the effect the committee's decisions about Cranfield Aeronautical College had had on the morale of the staff and, by implication, on the quality of the research carried out there. Dr. T. G. Halsall of the University of Oxford said that Cranfield was the single example available from which inferences could be drawn, and from the information he had received from colleagues there, the recommendations of the Public Accounts Committee were incompatible with the freedom to conduct the pattern of research which they would wish to conduct. This stung the chairman of the committee into a brisk exchange. "Are you aware that as a result of this committee's investigations in Cranfield, very considerable economies were achieved ?" Dr. Halsall replied, "I understand, sir, at the expense of very considerable developments and research". On academic freedom, Dr. K. Urwin, the general secretary of the association, suggested that there was greater emphasis on supplying places at universities for science and technology students than for arts students. This made it very much easier for a mediocre student to get in to read scientific subjects than to read arts subjects. If this trend were to continue, it might be interpreted as an intolerable infringement of academic freedom, although this was not yet the case. The association did not think that inspection by the Comptroller and Auditor-General would make this situation worse.

\section{Cost Effectiveness}

The difficulties of deciding when money is well spent were well illustrated by one exchange. Professor Griffiths asked if this meant universities should get tenders before they bought things. "That is one element of it," replied Sir Douglas Glover of the Committee of Public Accounts. "We do that now," said Professor Griffiths. "The point is, if we took the lowest tender, a Japanese estimate, which caused us to spend valuable money outside the country, would that be well spent?" The association repeated an argument used by the U.G.C. that the real safeguard for public money in university research was the fact that there was never enough of it, so that the internal struggles made sure that it was not wasted. Mr. M. Hookham of the University of Leicester said that the tenacity with which university lecturers fought proposals which they believed to be a waste of money was really quite remarkable. "Even the university chancellors do not know with what intensity this sort of thing is watched."

The committee was more deferential to its next witness, Lord Butler of Saffron Walden, among other things a former Minister of Education. Lord Butler said that there were dangers in enlarging the access of the Comptroller and Auditor-General to the detailed books and papers of the U.G.C. He said that it really was possible to criticize the shortness of money and expenditure rather than the laxity of the amount of money spent. His case rested on the psychological effect which the proposals would have, rather than any specific intrusion into university freedom.
His claim that "Dictatorship always starts by detailed criticism of the universities" did not, he said, imply any criticism of the present government. Lord Franks, Provost of Worcester College, Oxford, said that if the Comptroller and Auditor-General was to investigate universities, his net might well be spread even wider. "It is not obvious to me why, if this is the proper scope of the Comptroller and Auditor-General, he should not, on the same reasoning, have access to the records to the books and records of many other bodies besides the universities-for example, the nationalized industries, the $\mathrm{BBC}$, local government authorities, and indeed, private companies doing work under contract to government, especially where a great part of their work is of this kind". He added that he had had the impression that the activities of the Comptroller and Auditor-General resulted in a steady pressure towards uniformity.

\section{Auditing}

Lord Murray of Newhaven, Chancellor of the University of Southampton, feared that auditing would necessarily involve the Department of Education and Science more closely with the universities. "I think that the accounting officer would have to protect himself to meet his obligations as accounting officer for the universities. . . I think it would be difficult for him to stop at asking why as well as what expenditure is incurred". Lord Heyworth, a former member of the U.G.C. and a former chairman of Unilever, Ltd., said that the position of the academic members of the U.G.C. was delicate: "Only by the fact that nobody knows who contributed to what can they still retain the respect of their colleagues, and the U.G.C. can retain its authority". He said that central control would necessarily need formulae, and he did not believe that formulae were a reasonable means of reaching this kind of decision. "The interrelation between teaching and research elevates the element of judgment to such a degree that it really changes the whole operation".

Lord Robbins, Chairman of the Committee on Higher Education, held to the line established by his committee. "I regard the U.G.C. with its present functions as one of the most felicitous constitutional inventions of this century". Lord Robbins was unconvinced by the explanation that the Comptroller would not be concerned with academic matters; "I personally find it extremely difficult to believe that, with the best will in the world, the Comptroller and Auditor-General could avoid becoming involved in judgments of value and questions of policy if he were to undertake this particular function". This difficulty was retu "red to when Sir John Wolfenden gave further evidence, with several members of the U.G.C. "I find it difficult, as many of your other witnesses have found it difficult, to see how, if one investigates methodology, one can refrain from, perhaps, calling into question some of the decisions based on that methodology".

The last to give evidence was Sir Herbert Andrew, Permanent Under-Secretary of State at the D.E.S. He, too, thought it would be difficult for the Comptroller to avoid treading on academic toes. "It does seem to me that sooner or later questions would arise that would throw doubt on or put into question the allocations which the U.G.C. had made." Sir Herbert felt that any change might affect the standing of the U.G.C., and that the universities would become concerned if the position of the U.G.C. as a buffer were seen to move. Sir Herbert thought that the relation between the U.G.C. and the D.E.S. would have to be worked out again, which would be difficult, although perhaps not impossible. An audit would, he said, "make it a little bit easier for any government that was minded to extend control over the universities to do it". On the other hand, he thought that refusal to let the Comptroller and Auditor-General look at the books would hardly constitute a serious obstacle to any government that was so minded. 